\title{
EFEKTIVITAS PEMBELAJARAN DARING DENGAN MEDIA ONLINE BERBASIS GOOGLE CLASSROOM PADA POKOK BAHASAN GELOMBANG TERHADAP HASIL BELAJAR SISWA SMA N 2 TONDANO
}

\author{
Gela Lompad, Ferdy Dungus, Alfrits Komansilan \\ Fakultas Matematika dan Ilmu Pengetahuan Alam, Universitas Negeri Manado \\ email: gelalompad20@gmail.com
}

\begin{abstract}
ABSTRAK
Belajar merupakan kegiatan paling utama dari keseluruhan proses pendidikan disekolah. Merebaknya kasus pandemi Corona Virus Disease 2019 (Covid-19) sangat berdampak pada seluruh bidang yang ada, tak terkecuali pada bidang pendidikan proses belajar mengajarpun dilakukan dirumah secara daring atau online menggunakan Google.Penelitian ini bertujuan utuk mengetahui keefektifan pembelajaran daring dengan media Online berbasis Google Classroom pada pokok bahasan gelombang terhadap hasil belajar fisika siswa SMA Negeri 2 Tondano.Metode penelitian ini adalah metode eksperimen. Data penelitian ini berdasarkan hasil posttest. Rata-rata hasil belajar fisika siswa kelas eksperimen adalah 82 dengan skor maksimum 90 dan skor minimum 70 . Sedangkan rata-rata hasil belajar fisika siswa kelas control adalah 62 dengan skor maksimum 80 dan skor minimum 50. Uji normalitas data menunjukkan bahwa data kelas eksperimen dan kelas control berdistribusi normal,kemudian dilakukan uji hipotesis. Data hasil belajar siswa diperoleh dari posttest. Hasil penelitian dengan perhitungan rumus uji-t menunjukkan bahawa hipotesis $H_{O}$ ditolak. Sehingga dapat disimpulkan bahwa rata-rata hasil belajar fisika kelas eksperimen lebih tinggi dari pada rata-rata hasil belajar kelas kontrol.
\end{abstract}

Kata kunci : Media Google Classroom, Proses Belajar, Hasil Belajar

\begin{abstract}
Learning is the most important activity in the entire educational process in school. The outbreak of the Corona Virus Disease 2019 (Covid-19) pandemic has had a major impact on all existing areas; teaching and learning processes are also carried out at home online or online via Google in the education sector. This study aims to determine the effectiveness of online learning with Googlebased online media classroom waves on the physical learning outcomes of SMA Negeri 2 Tondano students This research method is an experimental method. The research data are based on the posttest results. The average physics learning outcomes of the experimental class students was 82 with a maximum score of 90 and a minimum score of 70. While the average physics learning outcomes for the control class students was 62 with a maximum score of 80 and a minimum score of 50, normality test of the data showed that the experimental class data and the control class are normally distributed, then the hypothesis is tested. Data on student learning outcomes from the post-test. The results of the investigation by calculating the t-test formula show that the $H_{-} O$ hypothesis is rejected. From this it can be concluded that the average learning outcomes of the experimental physics class are higher than those of the control classes.
\end{abstract}

Keywords : : Google Classroom Media, learning process, learning outcomes 


\section{PENDAHULUAN}

Belajar merupakan kegiatan paling utama dari keseluruhan proses pendidikan disekolah. Menurut Djamarah dan Zain (2010) belajar adalah perubahan perilaku berkat pengalaman dan latihan. Artinya tujuan kegiatan adalah perubahan tingkah laku, baik yang menyangkut pengetahuan, keterampilan maupun sikap bahkan meliputi segnap aspek organisme atau pribadi. Kegitan pembelajaran memerlukan keaktifan siswa, partisipasi dan komunikasi interaktif anatara guru dan siswa. Selain adanya hubungan antara peserta didik dengan lingkungannya, proses belajar ini juga dapat terlihat berlangsung karena adanya suatu interaksi yang dilakukan antara guru dan peserta didik.

Merebaknya kasus pandemic Corona Virus Disease 2019 (Covid-19) sangat berdampak pada seluruh bidang yang ada, tak terkecuali pada bidang pendidikan. Pendidikan formal yang biasanya dilakukan secara langsung di sekolah dengan melakukan tatap muka harus terkendala dengan adanya pandemic ini. Satu-satunya jalan keluar yang bias dilakukan yaitu kegiatan belajar mengajar bagi peserta didik dilakukan dirumah melalui media online baik menggunakan ponsel ataupun laptop. Hal tersebut dilakukan guna meminimalisir kontak fisik secara massal sehingga dapat memutus mata rantai penyebaran virus tersebut. Keamanan dan keselamatan peserta didik serta guru dan tenaga kependidikan itu yang utama. Menurut Gubernur Jawa Barat Ridwan Kamil (2020) mengatakan bahwa konsepnya bukan libur, tapi bersekolah dirumah dengan arahan para guru secara jarak jauh menggunakan system daring atau menggunakan $\mathrm{hp}$.

Berdasarkan perintah tentang pembelajaran Online maka satuan pendidikan untuk siswa sekolah menengah atas (SMA) proses belajar mengajarpun dilakukan dirumah secara Online.

Google Classroom adalah serambi pembelajaran campuran untuk ruang lingkup pendidikan yang dapat memudahkan pengajar dalam membuat, membagikan, dan menggolongkan setiap penugasan tanpa kertas (Mayangsari, dkk, 2019). Google Classroom ini dapat memudahkan peserta didik dan pengajar untuk saling terhubung di dalam dan di luar sekolah (Wicaksono, 2020).

Google Classroom selain lebih efisien juga mudah digunakan. Menurut Riyana (2008), media pembelajaran dapat berfungsi sebagai sarana yang dapat memberikan pengalaman visual kepada siswa antara lain untuk mendorong motivasi belajar, meskipun pembelajaran jarak jauh dengan system daring, hasil belajar siswa tetap menjadi focus utama dalam pembelajaran. Dan untuk memperoleh hasil belajar yang baik, diperlukan keefektifan pembelajaran daring agar tujuan pembelajaran dapat tercapai.

Fisika merupakan ilmu yang membahas teori yang berkaitan dengan gejalah alam dan keterkaitannya dengan kenyataan. Faktor yang melatar belakangi siswa kesulitan untuk memahami materi fisika adalah kurangnya pemahaman konsep dikarenakan kualitas pengajaran dan pembelajaran yang kurang baik (Asworth and Lucas, 2001; Lucas, 2000;2001;2002;2011). Pada masalah ini sangat dibutuhkan kreatifitas seorang pendidik dalam pembelajaran daring untuk menimbulkan daya tarik peserta didik dalam proses pembelajaran tersebut.

Berdasarkan uraian di atas, maka peneliti tertarik untuk melakukan penelitian dengan judul "Efektivitas pembelajaran daring dengan media Online berbasis Google Classroom pada pokok bahasan gelombang terhadap hasil belajar fisika siswa SMA Negeri 2 Tondano.

\section{METODE PENELITIAN}

\section{Tempat dan Waktu Penelitian}

Penelitian ini dilaksanakan di SMA N 2 Tonadano pada tahun ajaran 2020/2021

\section{Populasi dan Sampel}

1) Populasi

Populasi dalam penelitian ini adalah siswa kelas XI IPA A dan XI IPA B SMA N 2 Tondano tahun ajaran 2020/2021.

2) Sampel

Yang menjadi sampel dalam penelitian ini adalah siswa kelas XI IPA A yang berjumlah 20 orang siswa dan kelas XI IPA B berjumlah 20 orang siswa di SMA N 2 Tondano

\section{Jenis dan Desain Penelitian}

Berdasarkan judul dan permasalahan di atas maka jenis penelitain ini adalah eksperimen. Dalam penelitian ini, siswa dibedakan atas dua kelas yaitu kelas control dan 
kelas eksperimen. Kedua kelas ini diberi perlakuan yang berbeda. Pada kelas eksperimen dilakukan dengan melakukan pembelajaran dengan menghunakan media berbasis Google Classroom sedangkan kelas control dilakukan pembelajaran tanpa menggunakan media berbasis Google Classroom.

Desain yang digunakan dalam penelitian ini adalah Posttest-only Control Design (Sugiyono 2010).

Tabel 1. Posttest-only Control Design

\begin{tabular}{lcc}
\hline Group & Treatment & Postest \\
\hline Kelas eksperimen & $X_{1}$ & $0_{1}$ \\
\hline Kelas Kontrol & $X_{2}$ & $0_{2}$ \\
\hline
\end{tabular}

Keterangan :

$0_{1}$ : Tes hasil belajar pada kelas eksperimen dengan menggunakan media berbasis Google Classroom

$\mathrm{O}_{2}$ : Tes hasil belajar pada kelas control tanpa menggunakan media

$X_{1}$ : Perlakuan pada kelas eksperimen dengan menggunakan media berbasis Google Classroom

$X_{2}$ : Perlakuan pada kelas control tanpa menggunakan media

\section{Variabel Penelitian}

Pada penelitian ini terdapat dua variabel yaitu:

1. Variabel perlakuan

Variable perlakuan adalah efektivitas pembelajaran daring dengan media Online berbasis Google Classroom pada pokok bahasan gelombang melalui latihan dengan pola individu dan latihan dengan pola berpasangan pada siswa di SMA.

2. Variabel Respons

Variabel respons dalam penelitian ini adalah hasil belajar fisika khusus pada materi gelombang.

\section{Instrumen Penelitian}

Instrument yang digunakan pada penelitian ini berbentu tes. Tes yang diberikan terdiri dari soal posttest yang berbentuk soalsoal objektif.

\section{Teknik Pengumpulan Data}

Data yang akan dikumpulkan diperoleh dengan memberikan Posttest setelah dilakukannya treatment/perlakuan dengan menggunakan media berbasis Google Classroom pada kelas eksperimen dan perlakuan tanpa menggunakan media berbasis Google Classroom pada kelas kontrol.

\section{Teknik Analisis Data}

Untuk mengetahui perbedaan hasil belajar fisika siswa yang menggunakan media berbasis Google Classroom pada kelas eksperimen dan tanpa menggunakan media berbasis Google Classroom pada kelas control digunakan uji statistic. Dengan uji prasyarat yaitu uji normalitas dan uji homogenitas.

Uji normalitas data digunakan untuk mengetahui apakah sampel berdistribusi normal atau tidak. Uji statistic pada penelitian ini yaitu menggunakan uji liliefors dengan prosedur sebagai berikut:

$H_{O}$ : Sampel berasal dari populasi berdistribusi normal

$H_{A}$ : Sampel tidak berasal dari populasi berdistribusi normal

Dengan tingkat signifikasi $\alpha=5 \%=0,05$. Dengan menentukan nilai z

$$
z_{i}=\frac{x_{i}-\bar{x}}{S D}
$$

Uji signifikasi: nilai terbesar $F_{t}-$ $F_{S}$ dibandingkan dengan nilai table liliefors. Jika terbesar $F_{t}-F_{s}<t_{\text {tabel }}$ maka $H_{o}$ diterima $H_{a}$ ditolak. Jika nilai terbesar $F_{t}-F_{s}>t_{\text {tabel }}$ maka $H_{o}$ ditolak $H_{A}$ diterima.

Selanjutnya uji homogenitas data yang bertujuan untuk mengetahui apakah kedua varians data homogeny atau tidak homogeny digunakan uji-F dengan rumus :

$$
F \frac{\text { varians terbesar }}{\text { varians terkecil }} \frac{S_{1}^{2}}{S_{2}^{2}}
$$

Hipotesis statistik sebagai berikut:

$H_{O}: \sigma_{1}^{2}=\sigma_{2}^{2}$ (kedua varians/ragam sama)

$H_{1}: \sigma_{1}^{2} \neq \sigma_{2}^{2}$ (kedua varians/ragam tidak sama) Taraf nyata signifikasi $\alpha=5 \%$ dengan

Syarat erima $H_{O}$ jika $F_{O}<F_{\text {tabel }}$ dan tolak $F_{O}>F_{\text {tabel }}$.

Hipotesis Statistik

$H_{0}: \mu_{A} \leq \mu_{B}$

$H_{A}: \mu_{A}>\mu_{B}$

$H_{O}: \mu_{A} \leq \mu_{B}:$ Rata-rata hasil belajar fisika siswa kelas eksperimen yang diberi perlakuan dengan menggunakan media beebasis Google 
Classroom lebih kecil dari pada rata-rata hasil belajar fisika siswa kelas kontrol yang diberi perlakuan tanpa menggunakan media berbasis Google Classroom

$H_{A}: \mu_{A}>\mu_{B}$ : Rata-rata hasil belajar fisika siswa kelas eksperimen yang diberi perlakuan dengan menggunakan media berbasis Google Classroom lebih timggi dari pada rata-rata hasil belajar fisika siswa kelas kontrol yang diberi perlakuan tanpa menggunakan media berbasis Google Classroom.

\section{Uji Prasyarat t}

Pengujian normalitas data pada penelitian ini menggunakan uji liliefors yang di olah menggunakan software Microsoft Excel. Hasil uji normalitas dari posttest pada kelas eksperimen menunjukkan nilai $L_{\text {hitung }}=$ 0,175 dan $L_{\text {tabel }}=0,190$. Jadi $L_{\text {hitung }}$ lebih kecil dari $L_{\text {tabel }}$ yaitu $L_{O}=0,175<L_{t}=$ 0,190 . Berdasarkan kriteria pengujian adalah sampel berasal dari populasi yang berdistribusi normal.

Sementara uji normalitas dari posttest pada kelas kontrol menunjukkan nilai $L_{\text {hitung }}=0,183$ dan $L_{t a b l}=0,190$ jadi, Jadi $L_{\text {hitung }}$ lebih kecil dari $L_{\text {tabel }}$ yaitu $L_{O}=$ $0,183<L_{t}=0,190$. Berdasarkan kriteria pengujian adalah sampel berasal dari populasi yang berdistribusi normal.

Hasil analisis pengujian kesamaan dua varian/ragam dengan statistic uji $\mathrm{F}$ pada data selisih posttest dengan $F_{\text {hitung }}=1,454$ dan $F_{\text {tabel }}=2,168$. Berdasarkan kriteria pengujian jika $F_{O}<F_{t}$ maka $H_{O}$ diterima. Dengan demikian pengujian ini adalah varian dari kedua populasi asal sampel penelitian ini adalah homogennya.

\section{Pengujian Hipotesis}

Pengujian hipotesis pada penelitian ini yaitu membandingkan skor hasil belajar fisika siswa kelas eksperimen yang diberi perlakuan dengan menggunakan media online berbasis Google Classroom dengan skor hasil belajar fisika siswa kelas kontrol yang diberi perlakuan tanpa menggunakan media berbasis Google Classroom.

Data hasil pengujian hipotesis dengan ujit pada taraf nyata $\alpha=0,05$ diperoleh $t_{\text {hitung }}=$ $84,5>t_{\text {tabel }}=1,734$. Sesuai dengan keiteria pengujian jika $t_{\text {hitung }}>t_{\text {tabel }}$ maka $H_{O}$ diterima. Dengan demikian dapat disimpulkan bahwa rata-rata skor hasil belajar fisika siswa kelas eksperimen yang diberi perlakuan dengan menggunakan media online berbasis Google Classroom lebih tinggi dari pada rata-rata hasil belajar fisika siswa kelas kontrol tanpa menggunkan media berbasis Google Classroom.

\section{HASIL DAN PEMBAHASAN}

Berdasarkan hasil penelitian yang di adakan di SMA N 2 Tondano pada semester genap tahun ajaran 2020/2021 di kelas XI IPA A sebagai kelas eksperimen yang melakukan pembelajaran dengan menggunakan media berbasis Google Classroom yang berjumlah 20 orang dan kelas XI IPA B sebagai kelas kontrol yang melakukan pembelajaran tanapa menggunakan media berbasis Google Classroom yang berjumlah 20 orang. Menunjukkan bahwa terdapat perbedaan hasil belajar yang dicapai oleh siswa kelas eksperimen dan siswa kelas kontrol khusunya pada materi gelombang. Hal ini terbukti pada nilai Posttest yang dicapai oleh siswa ternyata memiliki perbedaan yang signifikasi yaitu siswa yang melakukam pembelajaran daring dengan media online berbasis Google Classroom lebih tinggi dibandingkan dengan siswa yang melakukan pembelajaran daring tanpa menggunakan media berbasis Google Classroom.

Dapat dilihat rata-rata hasil belajar fisika pada materi gelombang dari kelas eksperimen dan kelas control dapat dilihat dari data hasil posttest dibawah ini:

Tabel 2. Data hasil Posttest kelas eksperimen dan kelas control

\begin{tabular}{llll}
\hline No & Statistik & Nilai statistik \\
\cline { 3 - 4 } & & $\begin{array}{l}\text { Kelas } \\
\text { eksperimen }\end{array}$ & $\begin{array}{l}\text { Kelas } \\
\text { kontrol }\end{array}$ \\
\hline 1. & $\begin{array}{l}\text { Skor } \\
\text { Minimum }\end{array}$ & 70 & 50 \\
\hline 2. & $\begin{array}{l}\text { Skor } \\
\text { Maksimum }\end{array}$ & 90 & 80 \\
\hline 3. & Jumlah & 1,640 & 1,240 \\
\hline 4. & Rata-rata & 82 & 62 \\
\hline 5. & Ragam & 69,47368 & 101,0526 \\
\hline 6. & S. Deviasi & 8,335088 & 10,05249 \\
\hline
\end{tabular}

Pada data hasil penelitian yang di dapat tertera pada tabel di atas, diketahui pada hasil posttes untuk kelas eksperimen data terendah 70 dan data yang tertinggi 90 sedangakan pada kelas kontrol data terendah 50 dan data tertinggi 
80.

Data yang telah di tata dalam bentuk distribusi sesuai dengan frekuensinya kemudian dimasukkan ke dalam tabel distribu frekuensi bentuk tabel distribusi kelompok.

Tabel 3. Distribusi frekuensi rata-rata hasil belajar fisika tanpa menggunkan media berbasis Google Classroom

\begin{tabular}{cc}
\hline Skor & Frekuensi \\
\hline 50 & 6 \\
\hline 60 & 6 \\
\hline 70 & 6 \\
\hline 80 & 2 \\
\hline Jumlah & 20 \\
\hline
\end{tabular}

Tabel 4. Distribusi frekuensi rata-rata hasil belajar fisika dengan menggunkan media berbasis Google Classroom

\begin{tabular}{cc}
\hline Skor & Frekuensi \\
\hline 70 & 5 \\
\hline 80 & 6 \\
\hline 90 & 9 \\
\hline Jumlah & 20 \\
\hline
\end{tabular}

\section{KESIMPULAN}

Berdasarkan hasil penelitian yang di adakan di SMA Negeri 2 Tondano pada siswa kelas XI IPA A dan siswa kelas XI IPA B pada tahun ajaran 2020/2021 dalam pemebelajaran fisika khusunya pada bahasan pokok gelombang dapat di tarik kesimpulan bahwa pada kelas eksperimen rata-rata hasil belajar fisika yang diberi perlakuan dengan menggunkan media berbasis Google Classroom adalah 82 dengan skor maksimjm 90 dan skor minimjum 70 . Sedangkan untuk kelas kontrol rata-rata hasil belajar fisika siswa yang di beri perlakuan tanpa menggunakan media berbasis Google Classroom adalah 62 dengan skor maksimum 80 dan skor minimum 50 .

Dari hasil pengujian hipotesis dengan menggunkan statistic uji-t dengan taraf nyata $(\alpha)=0,05$ diperoleh hasil pengujian $t_{\text {hitung }}>$ $t_{\text {tabel }}$ maka $H_{O}$ ditolak yang berarti $H_{a}$ diterima. Dengan demikian dapat disimpulkan bahwa rata-rata skor hasil belajar fisika siswa kelas eksperimen yang diberi perlakuan dengan menggunkan media berbasis Google Classroom lebih tinggi dari pada rata-rata hasil belajar fisika siswa kelas kontrol yang diberi perlakuan tanpa menggunakan media berbasis Google Classroom.

\section{REFERENSI}

Amornchewin, R. (n.d). The Development of AQL Language Skil in Data Fefinition and Data Manipulatif Language Using Exercises with Quizizz for Students Learning En Ahmad, F. N. (n.d.). Efektivitas Pembelajaran Daring Dengan Menggunakan Google Classroom Pada Mata Pelajaran Matematika Di Madrasah Aliyah Darul Falah Batu Jangkih.

Ali Sadikin, A. H. (n.d.). Pembelajaran Daring di Tengah Wabah Covid-19. Jurnal Ilmiah Pendidikan Biologi, Volume 6, Nomor 02, Tahun 2020, Hal.214-224.

Andira Permata, Y. B. (n.d.). Keefektifan Virtual Class dengan Google Classroom dalam Pembelajaran Fisika Dimasa Pandemi Covid-19. Jurnal Inovasi Pendidikan Fisika dan Riset Ilmiah, Vol.4 No.1 Halaman: 27-33 Mei 2020.

Briliannur Dwi C, A. A. (n.d.). Analisis Keefektifan Pembelajaran Online di Masa Pandemi Covid-19.

Buku Fisika SMA/MA kelas XI karangan Indarti Aris Prasetyo Nugroho Naila Hilmiyana Syifa, Kurikulum 2013 revisi, penerbit Mediatama. (n.d.).

Idad Suhada, T. K. (n.d.). Pembelajaran Daring Berbasis Google Classroom Mahasiswa Pendidikan Biologi Pada Masa Wabah Covid-19.

Mahardini, M. M. (n.d.). Analisis Situasi Penggunaan Google Classroom Pada Pembelajaran Daring Fisika Jurnal Pendidikan Fisika Universitas Muhammadiyah Metro.

Mulyadi, E. (n.d.). Pembelajaran Daring Fisika Melalui Whatsapp, Google Form, Dan Email, Dalam Capaian Presensi Aktif Dan Hasil Belajar Peserta Didik Jurnal Karya Ilmiah Guru, Vol.5,No.1 Edisi Khusus KBM Pandemi COVID-19.

Mustakim. (n.d.). Efektivitas Pembelajaran Daring Menggunakan Media Online Selama Pandemi Covid-19 Pada Mata Pelajaran Matematika. Journal of Islamic Education, Vol 2, No 1, May 2020.

Palupi, S. K. (Dapartemen Pendidikan Nasional,2009.vi,361 hlm,:ilus $25 \mathrm{~cm}$ ). FISIKA untuk SMA dan MA Kelas XII. Jakarta: Pusat Perbukuan,.

Riskey Oktavian, R. F. (n.d.). Efektivitas Pembelajaran Daring Terintegrasi Di Era Pendidikan 4.0. Jurnal Pendidikan dan 
Ilmu Pengetahuan, Vol.20 No.2 Tahun 2020.

Sabara, S. d. (n.d.). keefektifan Google Classroom sebagai media pembelajaran.

Sudjana. (2009). metoda statistika. Bandung : tarsito.

Sugiyono. (2010). Metode Penelitian Pendidikan (pendekatan kuantitatif,kualitatif, dan R\&B). Bandung : PT ALFABETA.

Sugiyono. (2012). Metode Penelitian Pendidikan (Pendekatan Kuantitatif, Kualitatif, dan R\&B). Bandung : PT ALFABETA.

Fauzan Fauzan, F. A. (2019). The Effectiveness of Google Classroom Media on the Student's Learning Outcomes of Madrasah Ibtidaiyah Teacher Education Dapartement. Al Ibtida : Jurnal Pendidikan Guru MI.

Mannong, A. B. (2020). The Students' Eyesight : The Effevtiveness Of Learning-Based Application On Elt in Pandemic Era. English, Teaching, Learning, and Research Journal.

Okmawati, M. (2020). The Use of Google Classroom During Pandemic. Journal of English Language Teaching. 